\title{
Development of GIS Interface Tool for GAMES Model and Its Application to an Agricultural Watershed in Southern Ontario
}

\author{
Kishor Panjabi ${ }^{*}$, Nabil Allataifeh1, Chen Dai2, Ramesh Rudra1, \\ Pradeep Goel $^{3}$, Narayan Shrestha', Rituraj Shukla1 \\ ${ }^{1}$ School of Engineering, University of Guelph, Guelph, Canada \\ ${ }^{2}$ Ewaters Environmental Science and Technology (Shanghai) Co. Ltd., Shanghai, China \\ ${ }^{3}$ Environmental Monitoring and Reporting Branch, Ontario Ministry of the Environment, Toronto, Canada \\ Email: *kpanjabi@uoguelph.ca
}

How to cite this paper: Panjabi, K., Allataifeh, N., Dai, C., Rudra, R., Goel, P., Shrestha, N. and Shukla, R. (2018) Development of GIS Interface Tool for GAMES Model and Its Application to an Agricultural Watershed in Southern Ontario. Open Journal of Civil Engineering, 8, 312-325. https://doi.org/10.4236/ojce.2018.83024

Received: June 25, 2018

Accepted: September 14, 2018

Published: September 17, 2018

Copyright $\odot 2018$ by authors and Scientific Research Publishing Inc. This work is licensed under the Creative Commons Attribution International License (CC BY 4.0).

http://creativecommons.org/licenses/by/4.0/

(C) (i) Open Access

\begin{abstract}
Soil erosion is an important economic and environmental concern throughout the world. In order to assess soil erosion risk and conserve soil and water resources, soil erosion modeling at the watershed scale is imperative. The Guelph model for evaluating effects of Agricultural Management System on Erosion and Sedimentation (GAMES) is tailor-made for such applications; it, however, requires a significant amount of spatial information which needs to be pre-processed using a Geographic Information System (GIS). The GAMES model currently lacks any such automated tools. As such, the GAMES was loosely coupled to a GIS interface to manage the large spatial input data and to produce efficient cartographic representations of model output results. The developed interface tool was tested to simulate the Kettle Creek paired watershed in Southern Ontario, Canada. Result demonstrated that the GIS-assisted procedure increased the ability of the GAMES model in simulating such a spatially varied watershed and made the process more efficient and user-friendly. Furthermore, the quality of reporting and displaying resultant spatial output was also significantly improved. The developed GAMES interface could be applied to any watershed, and the enhancement could be used to assess soil erosion risk and conserve soil and water resources in an effective way.
\end{abstract}

\section{Keywords}

GAMES, GIS-Interface, Kettle Creek Paired Watershed, Hydrological Modeling, Erosion and Sediment Yield 


\section{Introduction}

Prior to the use of the computer-based hydrologic model and Geographic Information System (GIS) in hydrology and hydraulic projects, practitioners assembled a number of maps, imageries, stream network, and other relevant data from field surveys to perform manual preliminary hydrologic analyses such as catchment delineation [1] [2]. These manual methods were very laborious, time-consuming and inefficient [3]. The advancement in GIS technology, digital spatial data, and efficient computers has precluded the need for many of these labor-intensive techniques [4]. Developments in the field of GIS helped users to organize all forms of geographically referenced data as layers and various GIS software/tools such as the ArcGIS [5], enabled hydrologists to pre-process, view and analyze project-specific digital elevation model (DEM), soil, land-use, and hydro-meteorological data spatially [6]. Besides, several hydrologic functions are in-built to perform some of the preliminary investigations which have reduced the level of approximation and subjectivity involved [7]. Use of GIS technology in any hydrology project significantly improved the quality, accuracy, and timeliness of the final product [8]. Furthermore, GIS greatly simplifies the model set up and improves model performance [9]. Additionally, the GIS advancements enabled users to handle a large amount of data in a short time frame.

Another critical component of GIS is an enhancement of the visual understanding of the spatial inputs and output results by managers, decision-makers and the public-at-large [10]. Changing the inputs of land use or introducing best management practices (BMPs) to compare the subsequent output can be very helpful to identify the problem and ease the decision-making process. Similarly, specialized interfaces when linked to a GIS application have increased the popularity and usability of spatially distributed hydrological models and led them to greater use and wide acceptance [11].

Developments of GIS interface for the hydraulic/hydrologic model started in 1975 when the HEC-1 model was integrated using a grid-based model. The resulted model was named as HEC-SAM. In this approach, the GIS software was simply used as a database to feed input data to the model [12]. There are several different approaches to integrating GIS with simulation models such as; the embedding method, loose coupling and tight coupling methods [13] [14] [15] [16]. The loose coupling approach is the simplest as the GIS software and the hydrologic model exchange files, read some of its input data files from geo-database and produce resultant output in a format that allows processing and displays the results within the GIS software. This is a standard approach since it requires little or no modifications to model software [17] [18]. From the successes of the past two decades, hydrological modelers have recognized the benefits of integration of GIS software and hydrological models [19] [20]. The advancement in GIS technology and improved techniques for the integration of GIS with hydrological modeling has made hydrological models more efficient and user-friendly [21] [22] [23] [33]. 
The Guelph model for evaluating Effects of Agricultural Management Systems on Erosion and Sedimentation (GAMES) [24], developed at University of Guelph, Guelph, Ontario, Canada, is seasonal event-based soil erosion and sediment yield simulation model for analyzing watershed management practices and effects on nonpoint source pollution changes [25]. However, it was not coupled with any GIS tool. As such, model inputs at user-specified spatial units were not automated which made the model difficult and inefficient to use in areas with high-resolution spatial maps. Furthermore, analyses of model outputs which could greatly be enhanced with the use of any GIS platform was hampered. The GAMES model thus needed a much-needed upgrade in this respect. In this research, a GIS interface modeling tool has been developed which involved two distinct phases. This is the first attempt of this kind specifically to the GAMES model and hence is a novel work. In the first phase, the GAMES model was loosely coupled to a GIS interface by developing a GAMES-GIS model in a GIS system. Then, a GAMES input data generator model was developed in Microsoft Excel using the Visual Basic code in order to convert the processed GIS data in a format compatible with the input format of the GAMES model.

In the second phase, the previous two steps process with many manual-based sub-processes were automated by creating a user-friendly computer interface using C\# language. During these processes, no change was made in the source codes of the GAMES model. Hence, the main objective of this study is to present the development and evaluation of the GIS interface to the GAMES model in an agricultural watershed in Southern Ontario, Canada. This has resulted in enhancing the capabilities of GAMES model and making it more efficient and user-friendly.

\section{Games Model}

The GAMES model [24] provides estimates of soil loss by water erosion and subsequent delivery of sediment from a field to stream in agricultural watersheds. The model operates on the discretization of the watershed into field sized hydrologic response units (HRUs) with identical characteristics of land-use, soil type, and class of slope. This discretization process allows for the modeling of the basin with homogeneous irregularly shaped HRUs of the watershed. The model also accommodates spatial changes/variations in soil and crop management conditions.

The model comprises of two main components, soil loss component, and sediment delivery component. The potential soil erosion component is based on the Universal Soil Loss Equation (USLE) [26]:

$$
\mathrm{A}=2.424 \times \mathrm{R} \times \mathrm{K} \times(\mathrm{L} \times \mathrm{S}) \times \mathrm{C} \times \mathrm{P}
$$

where, $\mathrm{A}$ is computed site soil loss $\left(\mathrm{t} \mathrm{ha}^{-1} \mathrm{yr}^{-1}\right), \mathrm{R}$ is a seasonal or event rainfall erosivity factor $\left(\mathrm{MJ} \mathrm{mm} \mathrm{ha}{ }^{-1} \mathrm{~h}^{-1}\right.$ year $\left.^{-1}\right), \mathrm{K}$ is a soil erodibility factor $\left(\mathrm{t} \mathrm{h} \mathrm{MJ} \mathrm{J}^{-1} \mathrm{~mm}^{-1}\right)$, $\mathrm{L}$ is a slope length factor (unitless) that is often combined with $\mathrm{S}$ is a slope steep- 
ness factor, to yield a unitless terrain factor (LS), $\mathrm{C}$ is a unitless crop and land-use management factor, and $\mathrm{P}$ is a dimensionless erosion control practice factor. The $\mathrm{K}$ and $\mathrm{C}$ could vary from rainfall event to event and season to season.

The input parameters required for the model include land slope, channel slope, soil type, soil erodibility, cropping factors and location and efficiency of sediment detention structures. The sediment delivery from each HRU to downstream HRU and from HRU to the watershed's stream channels is determined by a delivery ratio, calculated based on physical characteristics of the HRU such as roughness and flow length assuming homogeneous characteristics of eroded sediments.

The model allows the estimation of potential soil loss and its delivery to streams during various seasons or events, thereby providing useful insights into the annual or seasonal or event variations and their distribution within the watershed. The model, therefore, provides a powerful tool for watershed soil erosion and sediment control planning. It facilitates implementation of efficient and economical ways to apply remedial control strategies and selection of BMPs for different areas of the watershed [27] [28]. The model has been evaluated in many Canadian provinces and other countries and has been adopted as an approach to control the nonpoint source of pollution by many governmental and non-governmental agencies [24] [29] [30].

\section{Development of the GIS Interface Tool}

A GIS interface for the GAMES model was developed in two phases.

In the first phase, an interface was developed using two different platforms (the ArcGIS and Microsoft EXCEL). The interface developed in the ArcGIS platform is termed as the GAMES-GIS model and the one developed in the Visual Basic EXCEL platform is termed as the GAMES Input Data Generator (GAMES-IDG) model [31].

The GAMES-GIS model was developed by stringing the geo-processes to run through specially designed dialogue boxes and all the input data layers; such as study area, soil properties, land use, drainage network, Digital Elevation Model (DEM) through the ArcGIS dialogues (Figure 1).

The GAMES-GIS model uses the capabilities of ArcGIS to extract, process and organize necessary information from the input layers to create the reference tables. Firstly, the Clip function of the ArcGIS is used to clip the soil, land use and drainage network feature files and the Mask function is used for masking the DEM input file for a given specified study area. The second step starts with filling the sinks of the raw DEM file and creates the slope, flow direction, and flow accumulation files. The flow paths are delineated from the flow accumulation raster using the "Greater than Equal" function and the input threshold flow accumulation value. The flow paths are fragmented into sections with a unique ID number which is later used to determine the HRUs. Then, flow direction file is used to define stream links using the Stream Link function and flow paths. Once 


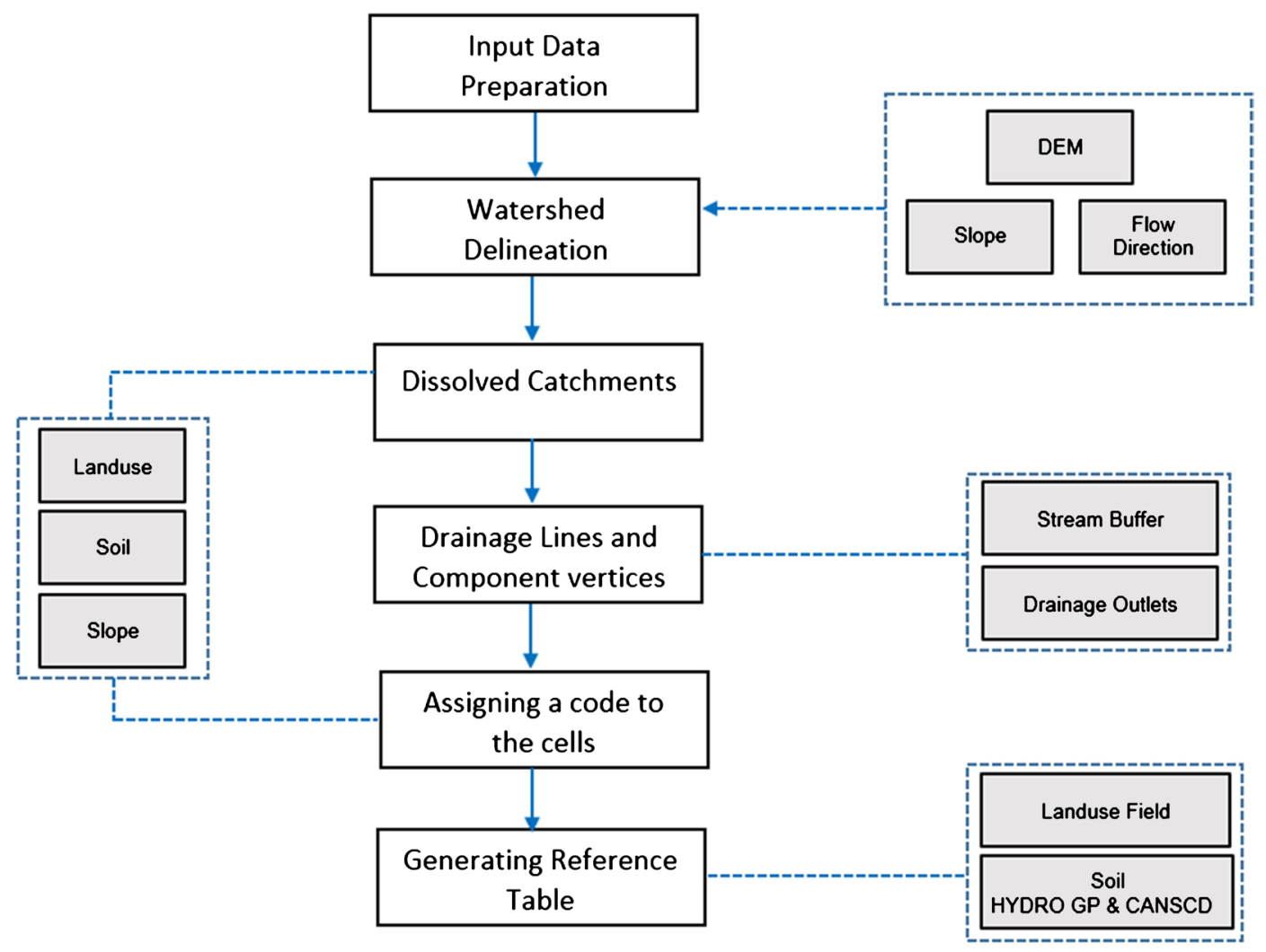

Figure 1. GAMES-GIS model workflow chart.

the stream links are created, the watershed is divided into Hydrologic Response Units (HRUs) using the Dissolve function and individual area of each HRU is calculated by the Calculate Area function. The stream link along with the flow direction file is used to create the drainage lines using the Stream to Feature function. Drainage lines are then used to decompose the flow paths into their component vertices; start points and end points using the function the Feature to Vertices.

The third step converts the land use and soil type layers from polygon to raster by using the Feature to Raster function. This step also creates two raster files from soil feature file denoting soil code (CANS_CD) and Hydrological group (HYDRO_GP) and one raster file denoting code of land use (LANDUNIT) from land-use feature file. The step four extracts the value of the slope, land use code (LANDUNIT), Hydrological group code (HYDRO_GP) and soil code (CANS_CD) by overlapping HRUs feature file over slope raster file and raster files created in the third step. The majority function of the zonal statistics function extracts a numerical value that appears most often within the HRU. This single value is then assigned to the entire HRU. In step five, the value of slope, land use code (LANDUNIT), Hydrological group code (HYDRO_GP) and soil code (CANS_CD) are assigned to each HRUs. This step also determines positions of the start point and end points along the flow path in the drainage network using point layers of starting points and end points. Finally, the sixth 
step generates reference tables for (LANDUNIT), Hydrological group code (HYDRO_GP) and soil code (CANS_CD) using "Raster to Polygon" function for each HRUs.

The GAMES-Input Data Generator (GAMES-IDG) model was developed using the Visual Basic programming language and added in Microsoft Excel as a Macro to generate an input file in the format required by GAMES model. The GAMES-IDG model creates an input file by extracting and organizing the data from various tables (DBF files) generated by the GAMES-GIS model. The model performs calculations in steps, and at each step, an interactive window pops up and prompts the user to load various files and/or parameters. In the first step, the GAMES-IDG model prompts the user to open the specific tables. Secondly, the GAMES-IDG model asks the user to enter information regarding project title, season under consideration and appropriate annual or seasonal or event runoff factor $(\mathrm{R})$ value in the first three lines for the input file. Thirdly, the GAMES-IDG model inputs the predetermined values for Soil erodibility factor $(\mathrm{K})$, Cropping factor $(\mathrm{C})$, and Manning's roughness (n) in the next three rows.

In the fourth step, the GAMES-IDG mode calculates flow path length (XLEN), soil erodibility value of HRU (K), integer code for C value (IC), SCS cropping factor index (ICROP), and the integer value of SCS soil classification (ISOIL) by sequence. Additionally, the values of HRU number (NUM), area of HRU (AREA), XLEN, slope of the flow path (SLO), K, IC, downstream HRU number in to which HRU drains (IDRAIN), ICROP and ISOIL are assigned to each HRU. In the fifth step, the values of HRU number (NUM), area of HRU (AREA), length of flow path (XLEN), slope of flow path (SLO), soil erodibility value of HRU (K), integer code for $\mathrm{C}$ value (IC), downstream HRU number in to which HRU drains (IDRAIN), SCS cropping factor index (ICROP) and integer value of SCS soil classification (ISOIL) are assigned to each HRU. In the sixth step, the total area of the watershed is calculated. Finally, the input file for GAMES model ("GAMESinput.xls") is created.

In the second phase, an interactive window interface (Figure 2) was built to integrate all the processes established in the first phase. This interface application was developed using C\# language. The user has to input the project title, and description in the interface text fields and the information regarding annual or seasonal or event rainfall erosion index values need to be supplied in the provided textboxes of the window. A drop-down menu is also provided to select the simulation season. The interface divides the whole simulation process into four steps. Firstly, it creates an input file for GAMES model. Secondly, it runs the GAMES model. Thirdly, it processes the GAMES output file. Finally, it converts the tabular output file into spatial layers by using the ArcGIS platform. Appropriate buttons are provided to carry out these steps in the interface.

As can be seen in Figure 2, the "Create Games Input" activates the process of generating an input file for GAMES model. In this step, the input data is loaded and previously developed GAMES_GIS model, and GAMES-IDG model performs 


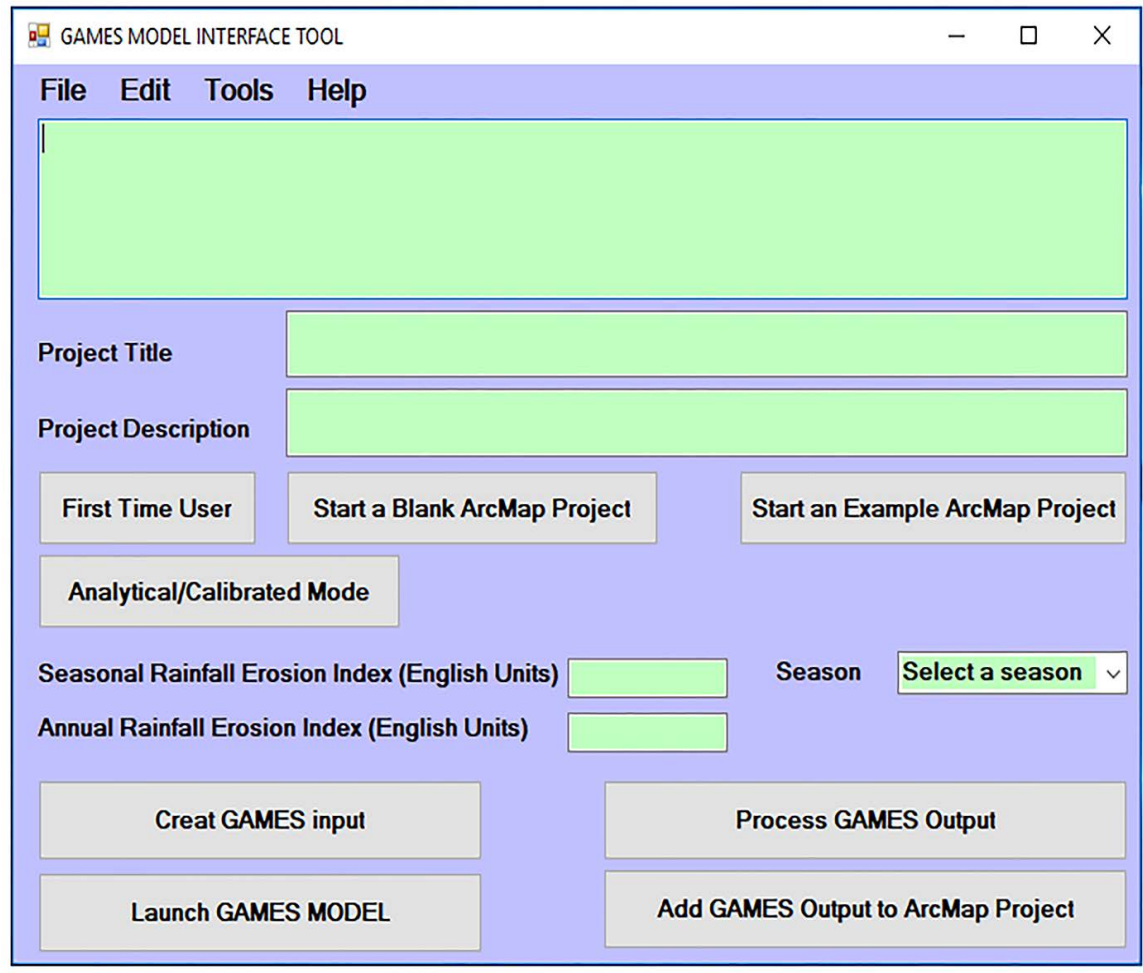

Figure 2. A screenshot of the GIS integrated GAMES model interface application.

the essential tasks to create the input text file (DAT) for the GAMES model. The "Launch GAMES Model" button activates the GAMES model to run using the input file. Once the simulation is completed, an output text file is generated. The resultant output text file is processed when the user hits the "Process GAMES Output" button. As such, soil erosion and sediment yield results are organized and converted into a tabular excel file format. The button "Add GAMES Output to ArcMap Project" adds and joins the tabular excel file with the attribute table of HRUs feature to create two new resultant layers showing soil erosion rate and sediment yield with pre-defined symbology.

\section{Application}

The developed interface was applied to model the erosion and sediment yield dynamics of the Kettle Creek paired watershed of southwestern Ontario, Canada.

\subsection{Study Area}

The Kettle Creek paired watershed drains two distinct watersheds of Madter (380 ha) and Holtby (355 ha) into their respective municipal drain which eventually flows to the Kettle Creek river, further flowing south through Elgin County into Lake Erie (Figure 3). Soils (Figure 4(b)) of both watersheds are a combination of moderately drained Brant silt loam and poorly drained Muriel silty clay loam. Farm systems in the watershed typically consist of row crops 


\section{Kettle Creek Paired Watersheds, London, ON, Canada}

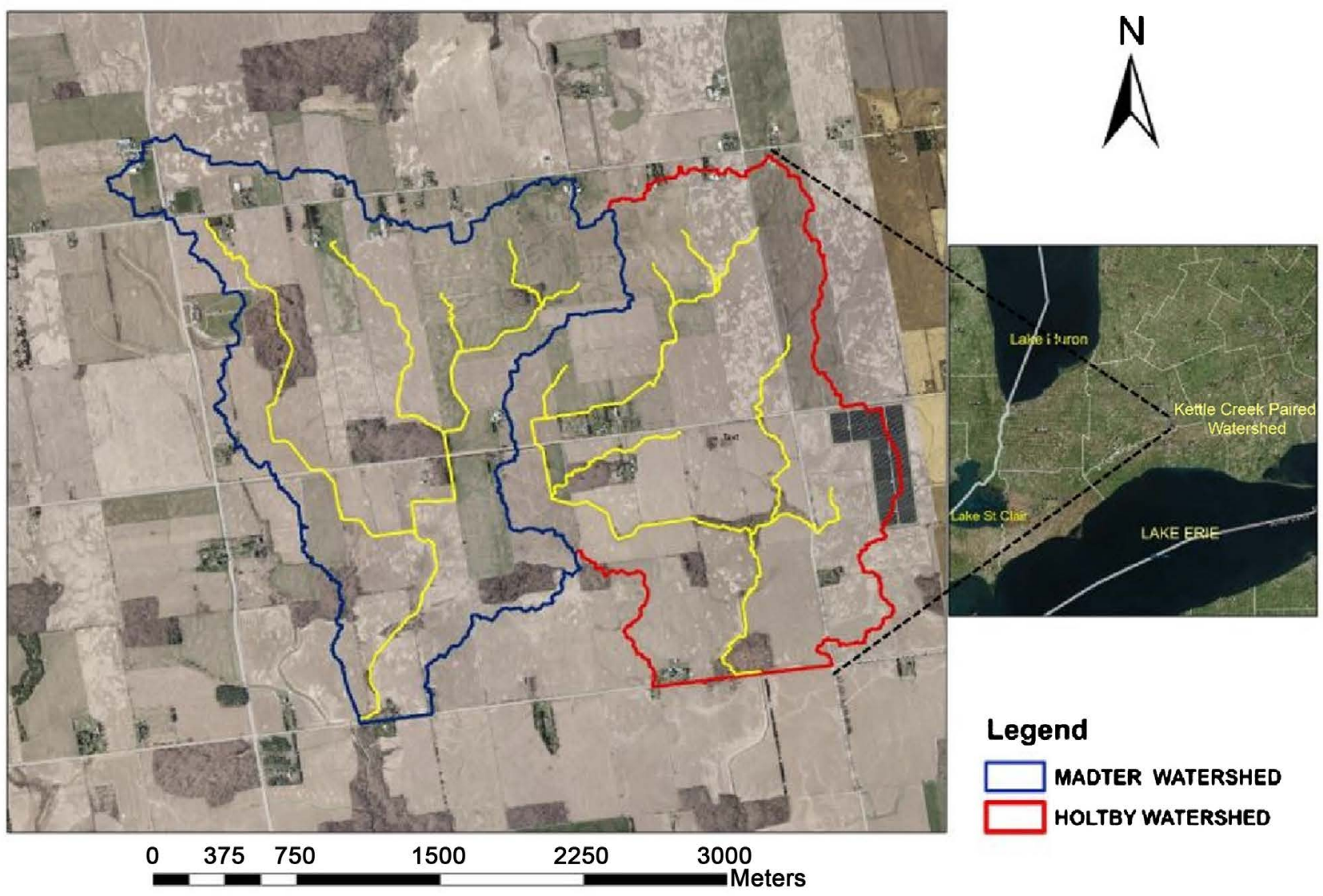

Figure 3. Two watersheds (Madter and Holtby) of the Kettle Creek paired watershed, Ontario, Canada with stream network. Also shown in the inset, is the location of the paired watershed with respect of Lake Huron and Lake Erie.

predominately corn, soybeans and winter wheat, but several cash crops with livestock systems also exist (Figure 4(c)). The main reasons of selecting the paired watershed are due to the availability of high-resolution spatial maps (DEM, soil, and land-use) as well as field-to-field crop management practices, and robust hydro-meteorological data set for model built-up, calibration and validation.

\subsection{Input Data}

The basic GIS data requirements of the developed interface include a sub-watershed boundary layer (polygon), digital elevation model (raster, Figure 4(a)), soil layer (polygon, Figure 4(b)), land-use layer (polygon, Figure 4(c)), and stream network layer. The annual rainfall erosion index (R) value of $100 \mathrm{MJ} \mathrm{mm} \mathrm{ha}{ }^{-1} \mathrm{~h}^{-1}$ $\mathrm{yr}^{-1}$, for the nearest climatic station (London, Ontario, Canada) was obtained from the study by Wall et al. 1983 [32]. The seasonal (R) value for spring, summer and fall were calculated to be 28,48 and 17 , respectively, using a procedure suggested by Wall et al. 1983 [32]. The GAMES-GIS model generates drainage lines (Figure 4(d)) and divided the watershed into land HRUs (Figure 4(e)) and created different layers of start points, endpoints and drainage lines (Figure 4(f)). 

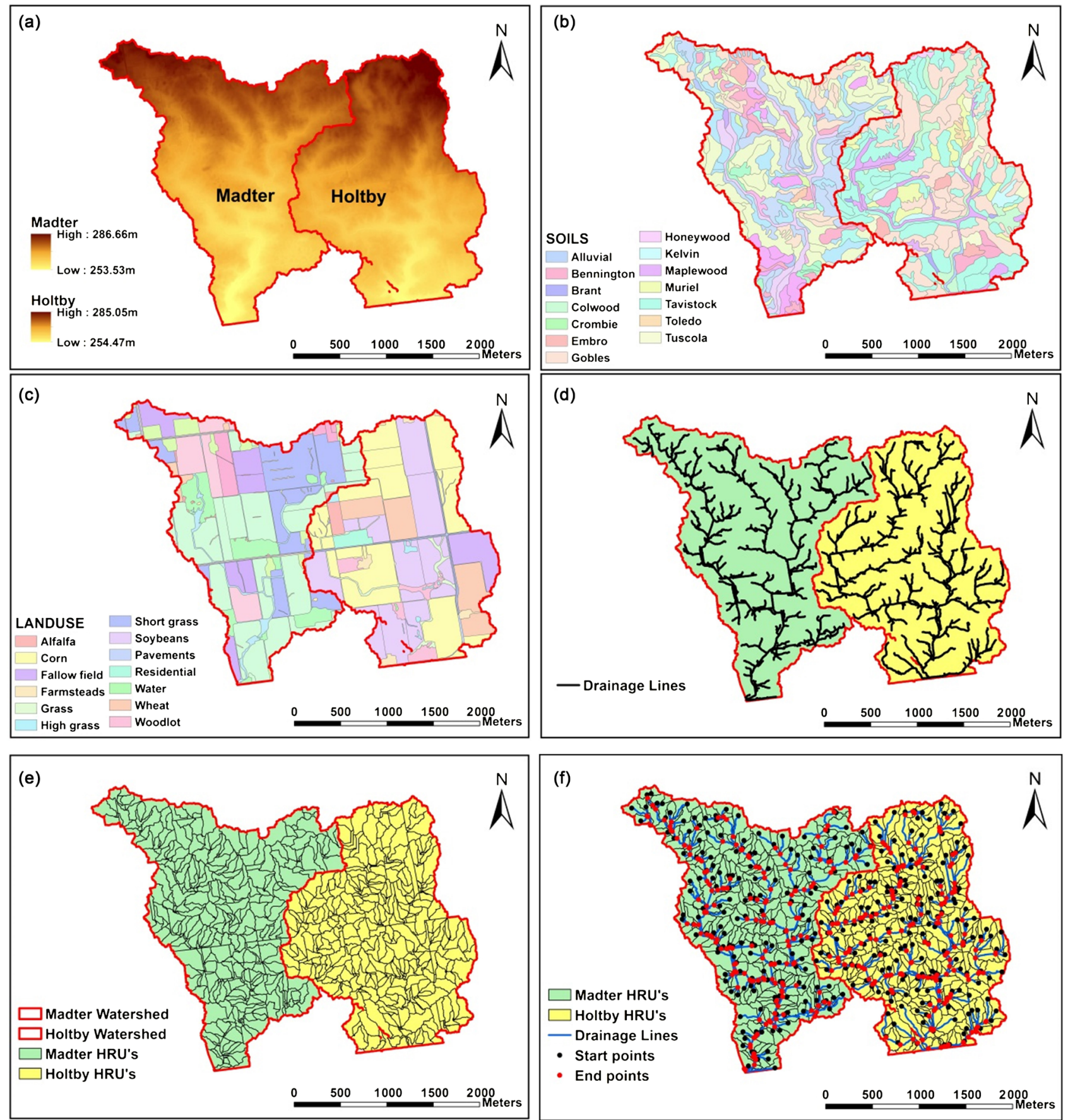

Figure 4. (a) DEM, (b) soil and (c) land use, (d) drainage lines (e) delineated HRUs and (f) start and end point of flow paths at both Madter and Holtby sub-watersheds of the Kettle Creek paired watershed.

The model assigned a unique soil type, land use, and slope to each HRU. The Soil Erodibility Factor (K), Cropping Factor (C), and Manning's Value (n) was assigned by the model for each HRU based on soil type, land use, and slope.

\subsection{Model Simulation Results}

As with any deterministic model, the accuracy of the results depends on the precise 

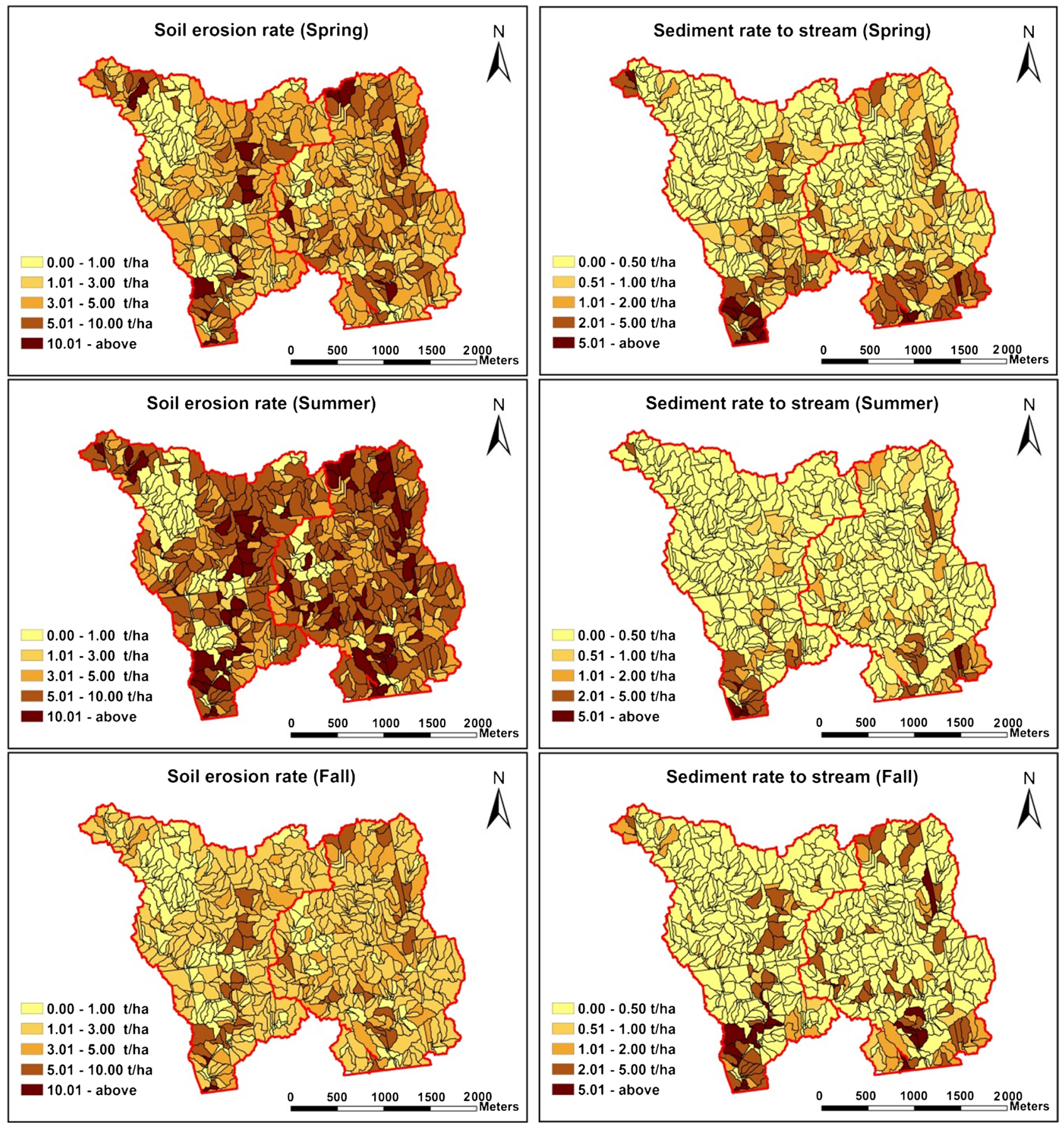

Figure 5. Erosion rate and sediment yield rate for spring, summer and fall seasons.

Table 1. Average erosion rate and sediment yield at different seasons of the year at two watersheds of Kettle Creek paired watershed.

\begin{tabular}{ccccccc}
\hline \multirow{2}{*}{ Watershed } & \multicolumn{2}{c}{ Spring } & \multicolumn{2}{c}{ Summer } & Fall \\
\cline { 2 - 7 } & Erosion (t/ha) & Sediment Yield (t/ha) & Erosion (t/ha) & Sediment Yield (t/ha) & Erosion (t/ha) & Sediment Yield (t/ha) \\
\hline Madter & 3.48 & 0.93 & 5.83 & 0.42 & 2.12 & 0.74 \\
Holtby & 4.04 & 0.98 & 6.75 & 0.44 & 2.45 & 0.79 \\
\hline
\end{tabular}


input data and selection of the parameter values of the model. The GAMES model is based both on parameters which can be physically measured and parameters which must be estimated with the help of literature and experience. The input data values such as cell area, cell slope, length of cell flow path, length of the flow path to the watershed outlet, and the drainage network are all physically measurable, and determination of these parameters can be accomplished with a reasonable degree of accuracy. The parameter values of USLE such as R, $\mathrm{K}, \mathrm{C}$ and delivery parameters such as $\mathrm{Hc}$ and $\mathrm{n}$ were selected using the literature and experience.

The GAMES model was run using the developed interface. The simulations for the Madter and Holtby sub-watersheds were performed separately. The model divided the Madter and Haltby watersheds into 352 and 360 HRU's respectively. The GAMES model created a tabular resultant output text file that included potential soil erosion, erosion rate, delivery ratio to the adjacent HRU, delivery ratio to the stream, sediment load, and sediment yield rate for every HRU. The developed GIS interface tool converted the output text file into excel format and loaded it to the ArcGIS. The excel file was then joined with the attribute table of the HRUs polygon file for displaying the results in spatial map format. Figure 5 shows, for the illustration purposes, some of the output maps such as total erosion and sediment yield rates for spring, summer and fall seasons.

The summary tables (Table 1) and GIS output maps (Figure 5) clearly illustrate the potential soil erosion and sediment yield of both the Matder and Holtby watersheds. It should be noted that the GAMES model has not been quantitatively validated on the field to field basis, as it is not the scope of the paper. However, qualitative field observations confirmed that the high soil loss and sediment yields areas simulated by the model exhibited significant soil losses and sediment yields. Similarly, areas predicted to have minimal soil losses, and sediment yield does exhibit these characteristics.

Hence, it has been illustrated that the developed GIS interface of the GAMES model has enhanced spatial data pre-processing and input, computational capability, and most importantly the output. Availability of GIS maps such as illustrated in Figure 5, would be crucial to identify the critical source areas of erosion and sediment yield, and that targeted BMPs could be placed over these areas in order to reduce the erosion as erosion is the source-related problem [33].

\section{Conclusion}

The study presented a novel development of a GIS-based interface tool for the GAMES model to manage the large spatial input data and to produce efficient cartographic representations of model output results. The developed interface tool was tested to simulate the Kettle Creek paired watershed in Southern Ontario, Canada. Based on the application, it can be concluded that the developed interface greatly enhanced the GAMES model as it allowed capturing, storing, 
managing, manipulating and analyzing large volumes of data, in an efficiently designed manner. The developed interface tool in its present form also demonstrated the flexibility of GIS technology in efficiently managing and processing the spatial data. The developed GAMES model interface can be applied to any watersheds, and the enhancement could be used to assess soil erosion risk and conserve soil and water resources in an effective way. While we demonstrated this new development in the Kettle Creek paired watershed by simulating erosion and sediment yield dynamics, the presented results are not validated robustly, and hence have to be taken as qualitative way. A more thorough validation of the model, identifying representing storm events of different durations at different seasons needs to be done in future.

\section{Conflicts of Interest}

The authors declare no conflicts of interest regarding the publication of this paper.

\section{References}

[1] Baxter, E.V. (2004) Distributed Hydrologic Modeling Using GIS. Springer, Berlin.

[2] Johnson, L.E. (2008) Geographic Information Systems in Water Resources Engineering. CRC Press, Boca Raton. https://doi.org/10.1201/9781420069143

[3] Merkel, W.H., Kaushika, R.M. and Gorman, E. (2008) NRCS GeoHydro-A GIS Interface for Hydrologic Modeling. Computers \& Geosciences, 3, 918-930. https://doi.org/10.1016/j.cageo.2007.05.020

[4] Viger, R.J. (2008) The GIS Weasel: An Interface for the Development of Geographic Information Used in Environmental Simulation Modeling. Computers \& Geosciences, 34, 891-901. https://doi.org/10.1016/j.cageo.2007.07.004

[5] Sui, D.Z. and Maggio, R.C. (1999) Integrating GIS with Hydrological Modeling: Practices, Problems, and Prospects. Computers, Environment and Urban Systems, 23, 33-51. https://doi.org/10.1016/S0198-9715(98)00052-0

[6] Lovell, L.T. and Atkinson, E. (2004) From Slide Rules to GIS: A 35-Year Evolution in Hydrologic and Hydraulic Engineering. Water Resources and Environment History Sessions at Environmental and Water Reources Institute Annual Meeting, Salt Lake City, 27 June-1 July. https://doi.org/10.1061/40738(140)2

[7] Robbins, C. and Phipps, S.P. (1996) GIS/Water Resources Tools for Performing Floodplain Management Modeling Analysis. AWRA Symposium on GIS and Water Resources, Fort Lauderdale, 22-26 September 1996. https://www.awra.org/ awra/proceedings/gis32/woolprt3/

[8] St. John, D. and Randolph, D. (2005) How Advances in GIS Improve Watershed Master Planning. Watershed Management Conference, Williamsburg, 19-22 July 2005. https://doi.org/10.1061/40763(178)57

[9] Savabi, M.R., Flanagan, D.C., Hebel, B. and Engel, B.A. (1995) Application of WEPP and GIS-GRASS to a Small Watershed in Indiana. Journal of Soil and Water Conservation, 50, 477-483.

[10] Daniel, E.B., Camp, J.V., LeBoeuf, E.J., Penrod, J.R., Abkowitz, M.D. and Dobbins, J.P. (2010) Watershed Modeling Using GIS Technology: A Critical Review. Journal of Spatial Hydrology, 10, 13-28. 
[11] Ogden, F.L., Garbrecht, J., DeBarry, P.A. and Johnson, L.E. (2001) GIS and Distributed Watershed Models. II: Modules, Interfaces, and Models. Journal of Hydrologic Engineering, 6, 515-523. https://doi.org/10.1061/(ASCE)1084-0699(2001)6:6(515)

[12] Males, R.M. and Grayman, W.M. (1992) Past, Present and Future of Geographic Information Systems in Water Resources. Water Resources Geographic Information Systems Issue, No. 87, The Universities Council on Water Resources.

[13] Bhatt, G., Kumar, M. and Duffy, C.J. (2014) A Tightly Coupled GIS and Distributed Hydrologic Modeling Framework. Environmental Modelling \& Software, 62, 70-84. https://doi.org/10.1016/j.envsoft.2014.08.003

[14] Castronova, A.M. and Goodall, J.L. (2013) Simulating Watersheds Using Loosely Integrated Model Components: Evaluation of Computational Scaling Using OpenMI. Environmental Modelling \& Software, 39, 304-313. https://doi.org/10.1016/j.envsoft.2012.01.020

[15] Goodall, J.L., Saint, K.D., Ercan, M.B., Briley, L.J., Murphy, S., You, H., DeLuca, C. and Rood, R.B. (2013) Coupling Climate and Hydrological Models: Interoperability through Web Services. Environmental Modelling \& Software, 46, 250-259. https://doi.org/10.1016/j.envsoft.2013.03.019

[16] Shrestha, N.K., Leta, O.T., De Fraine, B., van Griensven, A. and Bauwens, W. (2013) Open MI-Based Integrated Sediment Transport Modeling of the River Zenne, Belgium. Environmental Modelling \& Software, 47, 193-206. https://doi.org/10.1016/j.envsoft.2013.05.004

[17] Dean, D., Andrew, C. and James, E.B. (1995) GIS as Integration Tool for Hydrologic Modeling: A Need for Generic Hydrologic Data Exchange Format, ESRI User Conference.

[18] Dixon, B., Venkatesh, U. and Chittaranjan, R. (2015) GIS and Geo-Computation for Water Resource Science and Engineering. John Wiley \& Sons, Hoboken. https://doi.org/10.1002/9781118826171

[19] Kherde, R.V., Sawant, P.H. and Patel, S.V.B. (2013) Integrating Geographical Information Systems (GIS) with Hydrological Modelling-Applicability and Limitations.

[20] Moore, I.D. (1996) Hydrologic Modeling and GIS. In: Goodchild, M.F., Parks, B.O. and Steyaert, L.T., Eds., GIS and Environmental Modeling. Progress and Research Issues, GIS World Books, Fort Collins, 143-148.

[21] Khatami, S. and Khazaei, B. (2014) Benefits of GIS Application in Hydrological Modeling: A Brief Summary. Journal of Water Management and Research, 70, 41-49.

[22] Mahmoud, S.H. (2014) Investigation of Rainfall-Runoff Modeling for Egypt by Using Remote Sensing and GIS Integration. Catena, 120, 111-121. https://doi.org/10.1016/j.catena.2014.04.011

[23] Pontes, P.R.M., Fan, F.M., Fleischmann, A.S., Paiva, R.C.D., Buarque, D.C., Siqueira, V.A., Jardim, P.F., Sorribas, M.V. and Collischonn, W. (2017) MGB-IPH Model for Hydrological and Hydraulic Simulation of Large Floodplain River Systems Coupled with Open Source GIS. Environmental Modelling \& Software, 94, 1-20. https://doi.org/10.1016/j.envsoft.2017.03.029

[24] Rudra, R.P., Dickinson, W.T., Clark, D.J. and Wall, G.J. (1986) GAMES-A Screening Model of Soil Erosion and Fluvial Sedimentation on Agricultural Watershed. Canadian Water Resources Journal, 11, 58-71.

[25] Pandey, A., Himanshu, S.K., Mishra, S.K. and Singh, V.P. (2016) Physically Based 
Soil Erosion and Sediment Yield Models Revisited. Catena, 147, 595-620. https://doi.org/10.1016/j.catena.2016.08.002

[26] Wishmeier, W.H. and Smith, D.D. (1978) Predicting Rainfall Erosion Losses. U.S. Department of Agriculture.

[27] Mabit, L., Bernard, C. and Laverdière, M.R. (2002) Quantification of Soil Redistribution and Sediment Budget in a Canadian Watershed from Fallout Caesium-137 (137Cs) Data. Canadian Journal of Soil Science, 82, 423-431. https://doi.org/10.4141/S02-016

[28] Van Dijk, P.M. and Kwaad, F.J.P.M. (1998) Modelling Suspended Sediment Supply to the River Rhine Drainage Network; a Methodological Study. In: Summer, W., klaghoder, E. and Zhang, W., Eds., Modelling Soil Erosion, Sediment Transport, and Closely Related Hydrological Processes, IAHS, Wallingford, 165-176.

[29] Dickinson, W.T., Rudra, R.P. and Wall, G.J. (1986) Identification of Soil Erosion and Fluvial Sediment Problems. Hydrological Processes, 1, 111-124. https://doi.org/10.1002/hyp.3360010110

[30] Dickinson, W.T., Rudra, R.P., Sharma, D.N. and Singh, S.P. (1994) Employing a Watershed Model as a Basis for Planning a Sediment Monitoring Program. Canadian Water Resources Journal, 19, 289-303.

[31] Chen, D. (2006) GIS Interface for Games Erosion and Sedimentation Model. University of Guelph, Guelph.

[32] Wall, G.J., Greuel, J. and Dickinson, W.T. (1983) Rainfall Erosion Indices for Canada East of the Rocky Mountains. Canadian Journal of Soil Science, 63, 271-280. https://doi.org/10.4141/cjss83-027

[33] Rudra, R.P., Dickinson, W.T., Abedini, M.J. and Wall, G.J. (1999) A Multi-Tier Approach for Agricultural Watershed Management. JAWRA Journal of the American Water Resources Association, 35, 1159-1170. https://doi.org/10.1111/j.1752-1688.1999.tb04203.x 